\title{
Positive Regulation of Cell Differentiation
}

National Cancer Institute

\section{Source}

National Cancer Institute. Positive Regulation of Cell Differentiation. NCI Thesaurus.

Code C40738.

Cell Differentiation Induction involves initiation of progressive and normally irreversible processes whereby restriction of the developmental potential of immature precursor cells results in increasing specialization of cell function and morphology. 